\title{
Epoxidized Natural Rubber/Polyvinyl Chloride/Microcrystalline Cellulose (ENR/ PVC/MCC) Composite Membrane for Palm Oil Mill Effluent (POME) Treatment
}

(Membran Komposit Getah Asli Terepoksida/Polivinil Klorida/ Selulosa Mikrohablur (ENR/PVC/MCC) untuk Rawatan Efluen Kilang Minyak Kelapa Sawit (POME))

\author{
AinA AQILA ARMAN Alim \& RIZAFIZAH OTHAMAN*
}

\begin{abstract}
Epoxidized natural rubber/polyvinyl chloride/microcrystalline cellulose (ENR/PVC/MCC) composite membranes were prepared and used to treat palm oil mill effluent (РОME). The loadings of MCC were varied at 0, 5, 10 and $15 \mathrm{w} / \mathrm{w} \%$. The increment of MCC loads has intensified the hydroxyl peak of the membranes in FTIR spectrum, indicating the increase in membrane hydrophilicity. MCC acted as a pore forming agent since the ENR/PVC/10\% MCC gave the highest water flux and well-distributed pores. After first treatment of POME, the levels of chemical oxygen demand (COD), biochemical oxygen demand (BOD) and total suspended solid (TSS) were reduced to 99.9\%, 70.3\%, and 16.9\%, respectively. These data showed that ENR/PVC/MCC membrane has the potential to treat POME.
\end{abstract}

Keywords: Composite membrane; epoxidized natural rubber; microcrystalline cellulose; polyvinyl chloride; pore forming agent

\section{ABSTRAK}

Membran komposit getah asli terepoksida/polivinil klorida/selulosa mikrohablur (ENR/PVC/MCC) telah disediakan dan digunakan untuk rawatan efluen kilang minyak kelapa sawit (POME). Penambahan MCC telah divariasikan pada 0, 5, 10 dan 15 w/w\%. Penambahan MCC telah meningkatkan puncak hidroksil membran melalui spektrum FTIR yang menunjukkan peningkatan sifat hidrofilik membran. MCC juga bertindak sebagai ejen penjanaan liang disebabkan oleh bacaan ujian fluks air yang paling tinggi dan taburan liang yang sekata pada membran ENR/PVC/10\% MCC. Selepas rawatan POME yang pertama, tahap permintaan oksigen kimia (COD), permintaan oksigen biokimia (BOD) dan jumlah pepejal terampai (TSS) masing-masing telah berkurang sebanyak 99.9\%, 70.3\%, dan 16.9\%. Oleh itu, membran ENR/PVC/MCC didapati berpotensi untuk merawat POME.

Keywords: Agen penjanaan liang: getah asli terepoksida; membran komposit; polivinil klorida; selulosa mikrohablur

\section{INTRODUCTION}

The palm oil industry is one of the major agro-industries in Malaysia. Palm oil mill effluent (POME) is a waste produced from palm oil industry and it is compulsory to treat the waste before being released into the environment. Hassan et al. (2016) reported that POME is considered as non-toxic waste, but it is identified as one of the major contributors that deplete the dissolved oxygen once untreated POME is discharged into the water bodies.

Several innovative treatment technologies have been developed and applied to treat POME. Biological treatment requires large treatment area with long treatment period to break down the organic matter content in wastewater. This treatment also needs proper maintenance and monitoring as being reported by Ahmad et al. (2013). Besides, chemical residues and total suspended solids (TSS) are still present after the physical and chemical treatment processes (Bala et al. 2014).

Membrane technology is one of the potential solutions for the treatment of POME since the current conventional treatment system shows the lack of efficiency. The advantages for membrane separation are low energy consumption, room temperature operation and less chemical usage (Rambabu \& Velu 2016). Membrane technology has been widely applied in water and wastewater treatment for complete separation of particulate matters and microbial pathogens of larger size than the pore size of the membrane (Sadr \& Saroj 2015). However, the POME treatment with membrane technology has been restricted by its high cost of installation. Conducting a pretreatment process to lower the amount of waste that can cause damage and fouling before applying ultrafiltration membrane separation can reduce the cost. Similar findings have been reported by Azmi and Yunos (2014). A study by Ghaee et al. (2015) reported that membrane technology is an attractive method to treat the effluents from industries because it is effective and capable to meet the standard set by Department of Environmental (DOE).

Membrane can be made from rubbery materials such as natural rubber as they are non-porous. The addition of organic filler during membrane-making process will help in creating and enhancing the pores. Samad et al. (2014) 
reported the similar observations for other fillers. ENR is a hydrophilic elastomer with high shearing and flexibility while PVC is a thermoplastic with good mechanical strength and excellent chemical properties (Jon et al. 2013). Tanjung et al. (2015) stated that the blending of ENR-50 and PVC could produce a miscible blend due to the formation of hydrogen bonds between chlorine groups of PVC and epoxy groups of ENR. Compared to other fillers, MCC has been commonly used as reinforcement for polymers blending due to the advantages of biodegradable, renewable, low density, low cost and good mechanical properties (Zhang et al. 2016).

In this study, the porous and flexible ENR/PVC/MCC composite membranes were prepared with various loadings of MCC at 0, 5, 10 and $15 \mathrm{w} / \mathrm{w} \%$. The effects of MCC loadings were studied to measure the physical properties of the membrane. It is demonstrated that ENR/PVC/10\% MCC membrane could act as a promising membrane material to treat wastewater especially POME.

\section{MATERIALS AND METHODS}

\section{MATERIALS}

Epoxidised natural rubber with $50 \%$ epoxidation level, ENR-50 (Mw $=640000 \mathrm{~g} / \mathrm{mol})$ was obtained from Rubber Research Institute of Malaysia (RRIM). Polyvinyl chloride (PVC) $(\mathrm{Mw}=97000 \mathrm{~g} / \mathrm{mol})$ and microcrystalline cellulose powder (MCC) were purchased from Sigma Aldrich. Tetrahydrofuran (THF) $(\mathrm{Mw}=72.11 \mathrm{~g} / \mathrm{mol}$ ) with $99.8 \%$ purity was supplied by Systerm.

\section{PREPARATION OF COMPOSITE MEMBRANE}

The ENR/PVC 60:40 (w/w\%) matrix was prepared using solution blending technique based on the work by Nor and Othaman (2015) with modification. ENR/PVC matrix was dissolved in THF at the ratio of 1:8 w/v for $24 \mathrm{~h}$. ENR was swelled in THF and stirred vigorously until a homogenous solution was obtained. Then, PVC powder was added and stirred continuously until a homogenous solution was obtained. For the preparation of ENR/PVC/MCC membrane, various loadings of microcrystalline cellulose powder, 250-125 $\mu \mathrm{m}(0,5,10$ and $15 \mathrm{w} / \mathrm{w} \%)$ were added into the ENR/PVC solution and stirred continuously to ensure that the added MCC was finely dispersed. The membrane solution was then degassed for $0.5 \mathrm{~h}$ to release air bubbles. Next, the solution was poured onto the glass plate and casted using a casting knife with adjusted thickness of $0.35 \mathrm{~mm}$. After 2 min, the casted membrane was immersed in a coagulation bath (distilled water) for solvent exchange until white solid membrane appeared. Lastly, the membrane was peeled off from the glass plate and dried at ambient temperature.

\section{CHARACTERIZATION OF COMPOSITE MEMBRANE FTIR STUDY}

The functional groups of the membranes were determined using FTIR Perkin-Elmer spectrometer model (Spectrum
GX) in a range of wavenumber from $400-4000 \mathrm{~cm}^{-1}$. For thin film samples, the membranes was cut and placed on the sample holder. Then, the obtained data was interpreted to determine the functional group present in the membrane sample.

\section{MORPHOLOGY}

The surface morphology and cross section of the membranes were examined using ZEISS scanning electron microscope SUPRA 55VP model. The membranes were immersed in liquid nitrogen before being fractured and then sputter coated with gold to provide conductivity to the membranes. The average pore size of 150 pores on the membrane surface and the thickness of the membranes were measured using ImageJ software.

\section{WATER ABSORPTION AND MEMBRANES POROSITY}

The water absorption test was run according to Shamsuddin et al. (2013). The membranes were soaked in distilled water for $24 \mathrm{~h}$. Then, the excess water on the wet membrane surface $\left(W_{w}\right)$ was removed using filter paper. These membranes were dried in a vacuum oven, at $60^{\circ} \mathrm{C}$ for $24 \mathrm{~h}$ and the dried membranes weight mass $\left(W_{d}\right)$ was recorded. Equation (1) and (2) were used to calculate the percentage of water absorption and porosity of the membranes (Alomayri et al.2014):

$$
\begin{aligned}
& \text { Water absorption }(\%)=\frac{W_{w}-W_{d}}{W_{d}} \times 100 \\
& \text { Water porosity }(\%)=\frac{W_{w}-W_{d}}{A h} \times 1000
\end{aligned}
$$

where $W_{w}$ and $W_{d}$ are the weight of the wet membrane and dry membrane $(\mathrm{g})$, respectively. $A$ is the surface area $(\mathrm{mm})$ and $h$ is the membrane thickness ( $\mathrm{mm})$.

\section{FILTRATION PROCEDURE}

Water flux was carried out to determine the quantity of water permeated through the membrane at certain pressure using stirred cell Sterlitech HP4750 model as shown in Figure 1. The experiment was carried out in $250 \mathrm{~mL}$ capacity batch cell, with $43.36 \mathrm{~mm}$ area of membrane. The top end piece of the cell contained a feed and a gas inlet. Nitrogen gas $\left(\mathrm{N}_{2}\right)$ was used to pressurize the cell to operate pressures from 1 to 5 bar. For water flux, the magnetic bar was not being used during the filtration. The quantity of water permeated was recorded and measured by using (3) (Lau et al. 2015):

$$
\text { Flux }=\frac{Q}{A \Delta t}
$$

where $Q$ is water quantity that permeate through the membrane $(\mathrm{L}) ; A$ is the surface area of the membrane $\left(\mathrm{m}^{2}\right)$; 
$\Delta \mathrm{t}$ is retention time (h); and $P$ is pressure of $\mathrm{N}_{2}$ gas (bar). The graphs of water flux versus pressure were plotted.

\section{POME TREATMENT}

The POME treatment was carried out using the same stirred cell as shown in Figure 1. For stirred experiment, the magnetic bar was used during the filtration process. Then, the cell was stirred with magnetic stirrer at $500 \mathrm{rpm}$ stirring speed during the filtration process. The quantity of treated POME was recorded and calculated using (3). The graph of POME flux versus time were plotted. Four parameter in terms of chemical oxygen demand (COD), biochemical oxygen demand (BOD), total suspended solid (TSS) and $\mathrm{pH}$ were analyzed for raw and treated POME.

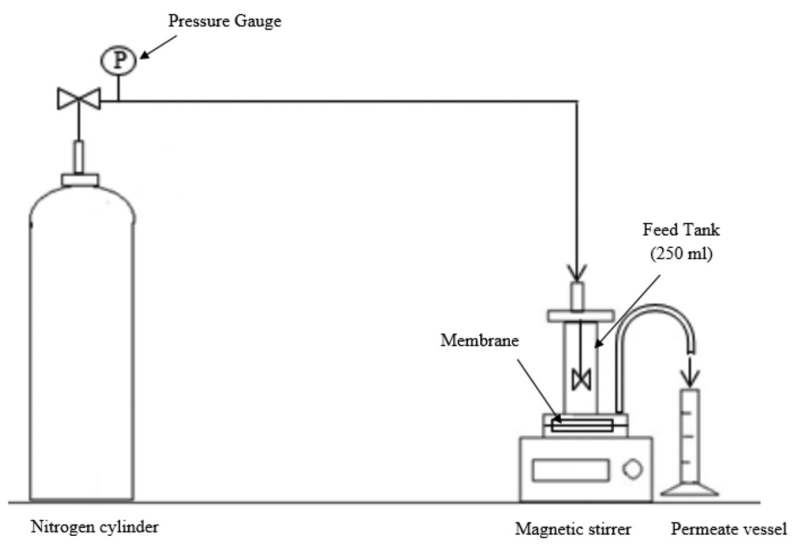

FIGURE 1. Schematic of dead end cell

\section{CHEMICAL OXYGEN DEMAND (COD)}

COD was determined by measuring the amount of oxidizing agent (potassium dichromate) being used to oxidize the organic matter contents in the sample (Chong et al. 2013)which involve scheduled sampling and chemical analysis can be expensive and time consuming. Therefore cheaper and faster alternatives to monitor wastewater characteristics are required as alternatives to conventional methods. This paper reviews existing conventional techniques and optical and fibre optic sensors to determine selected wastewater characteristics which are colour, Chemical Oxygen Demand (COD. COD was expressed in $\mathrm{mg} / \mathrm{L}$, which indicates the mass of oxygen consumed per liter of solution. The sample was analyzed based on the $\mathrm{HACH}$, Method 8000 (JAS 2011). The removal efficiency of COD was calculated using (4) (Bala et al. 2014):

The equation for COD, BOD and TSS:

$$
R_{C O D}(\%)=\frac{C O D_{0}-C O D_{1}}{C O D_{0}} \times 100
$$

where $C O D_{0}$ is the value of oxygen demand $(\mathrm{mg} / \mathrm{L})$ for raw POME meanwhile $C O D_{1}$ is the value of oxygen demand $(\mathrm{mg} / \mathrm{L})$ for treated POME using membrane.

\section{BIOCHEMICAL OXYGEN DEMAND (BOD)}

Biochemical oxygen demand was determined by measuring the amount of oxygen needed by microorganisms to decompose the organic matter contents present in the sample (Jouanneau et al. 2014). It is commonly expressed in milligrams of oxygen consumed per liter of sample during 5 days $\left(\mathrm{BOD}_{5}\right)$ of incubation at $20^{\circ} \mathrm{C}$. BOD was then determined by subtracting the fifth meter reading from the first reading. The sample was analyzed based on the APHA 2520 D standard method (JAS 2011). The removal efficiency of BOD was calculated using (5) (Bala et al. 2014):

$$
R_{B O D}(\%)=\frac{B O D_{0}-B O D_{1}}{B O D_{0}} \times 100
$$

where $B O D_{0}$ is the value of oxygen demand $(\mathrm{mg} / \mathrm{L})$ for raw POME meanwhile $B O D_{1}$ is the value of oxygen demand $(\mathrm{mg} / \mathrm{L})$ for treated POME using membrane.

\section{TOTAL SUSPENDED SOLID (TSS)}

The amount of suspended solid refers to the mass (mg) or concentration $(\mathrm{mg} / \mathrm{L})$ of inorganic and organic matter contents in wastewater (Shah et al. 2014). The trapped particles on the filter were determined. This test was performed according to APHA $2540 \mathrm{D}$ standard method (JAS 2011). The removal efficiency of TSS was calculated using equation (6) (Bala et al. 2014): The equation for COD, BOD and TSS:

$$
R_{T S S}(\%)=\frac{T S S_{0}-T S S_{1}}{T S S_{0}} \times 100
$$

where $T S S_{0}$ is the total suspended solid $(\mathrm{mg} / \mathrm{L})$ contents in raw POME meanwhile $T S S_{1}$ is the total suspended solid $(\mathrm{mg} / \mathrm{L})$ contents in treated POME using membrane.

\section{pH TEST}

The $\mathrm{pH}$ for raw and treated POME was measured by $\mathrm{pH}$ meter. This test was performed according to APHA $4500-\mathrm{H}^{+}$ B standard method.

\section{RESULTS AND DISCUSSION}

\section{ENR/PVC/MCC COMPOSITE MEMBRANE}

Figure 2 shows the appearance of composite membrane from epoxidized natural rubber (ENR), polyvinyl chloride (PVC) and microcrystalline cellulose (MCC) powder. It is a microfiltration. The membrane was transparent. The thickness during casting was $0.35 \mathrm{~mm}$ while the average thickness of dried membrane was around $0.02 \pm 0.01$ $\mathrm{mm}$. The solvent evaporated from the membrane surface, resulting in the reduction of membrane thickness. 


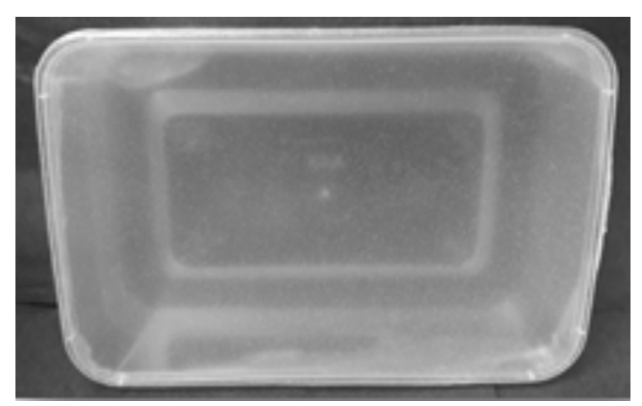

FIGURE 2. ENR/PVC/MCC composite membrane

\section{FTIR ANALYSIS}

Figure 3 shows the FTIR spectra for ENR/PVC membrane with different MCC loadings (0, 5, 10 and $15 \mathrm{w} / \mathrm{w} \%)$. FTIR results indicate that the increment of MCC increased the hydroxyl $(-\mathrm{OH})$ stretching at the absorption peaks of $3480 \mathrm{~cm}^{-1}$ (Ramesh et al. 2017). Apart from that, similar absorption peaks for all membranes were observed in the range of $2830 \mathrm{~cm}^{-1}$, which corresponded to $\mathrm{C}-\mathrm{H}$ stretching while the peak at $1450 \mathrm{~cm}^{-1}$ referred to $\mathrm{C}-\mathrm{H}$ bending. The peak at $1650 \mathrm{~cm}^{-1}$ in all membranes spectrum showed the presence of olefinic unsaturation group in the rubber. The results were consistent with the ENR/PVC/silica membrane studied by Jon et al. (2013). The absorption peaks at 1253, 1065 and $875 \mathrm{~cm}^{-1}$ were corresponded to C-O symmetric stretching due to the presence of epoxy group in the ENR (Samad et al. 2014). C-Cl group from PVC was assigned at $695 \mathrm{~cm}^{-1}$ absorption peak (Marbelia et al. 2016). There was no shifted peak because there is no chemical interaction between MCC and the membrane matrix .

\section{MEMBRANE MORPHOLOGY}

Pores formation for ENR/PVC membranes with different loadings were clearly seen from the surface morphology micrographs as observed in Figure 4. ENR/PVC/0\% MCC membrane has tiny pores on the surface and deformed pores on the cross section. The through pores started to develop after the addition of MCC. The formation of pores occurred due to several phenomena (Shamsuddin et al. 2013). First, the pores are generated due to the phase inversion process during the membrane preparation. Some of the solvent evaporate from top surface of the spread polymer solution while remaining solvent will diffuse into the water. The solvent-water exchange occurred during the phase inversion process. Some of the fillers leached out from the membrane, leaving voids inside the composite due to high affinity of MCC towards water while other fillers remained in the composite (Demirel et al. 2017; Jon et al. 2013). Similar observations have been reported by Chen et al. (2010). As the water evaporated during the drying process, water molecule left a gap between the matrixes. The pores might also be developed from the agglomeration of the filler. In this case, the MCC particles tend to agglomerate among each other. This situation led to the presence of spaces between MCC. The weak interaction of filler-filler produced cavities on the composite membrane that caused the pores formation (Shamsuddin et al. 2013).

The micrograph in Figure 4(b) shows the surface of the membrane filled with small pores after the addition of $5 \mathrm{w} / \mathrm{w} \%$ MCC. The highly distributed and even pores can be observed from ENR/PVC/10\% MCC membrane (Figure 4(c)). From Figure 4(d), it can be seen that the membrane surface is uneven which might be due to MCC agglomerations in the composite. The agglomeration of filler might also block the pores on the membrane surface (Ong et al. 2015). The formation of large filler agglomeration resulted in uneven distribution of filler and subsequently resulting in large pores formed in the membrane. This occurred because of poor interaction between filler and rubber matrix (Viet et al. 2008). Klaysom et al. (2011) highlighted that the rubber-filler interactions are weakened with increasing filler loadings. Based on Figure 5, the organic molecules and suspension in raw POME might be deposited on the membrane surface and inside the pores of the membrane, thus affecting the permeability rate of POME (Madaeni et al. 2013).

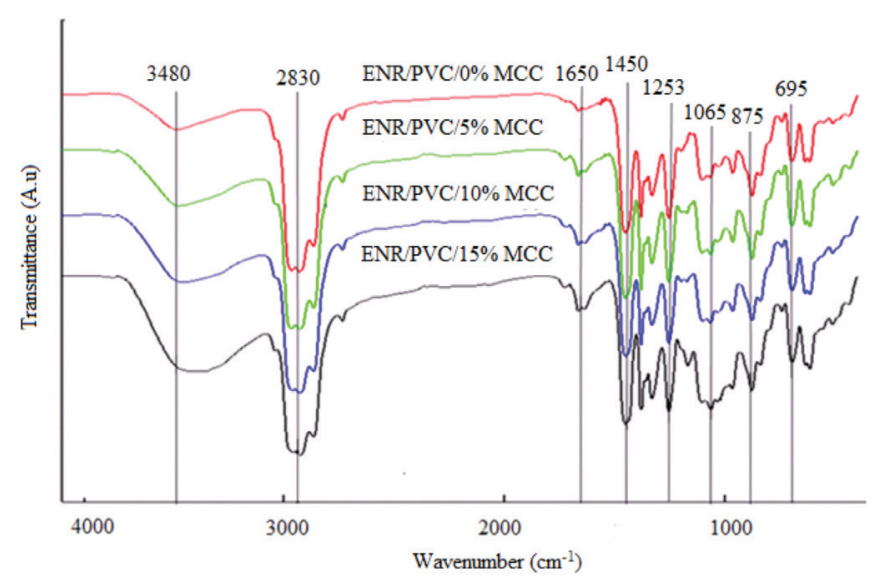

FIGURE 3. FTIR spectrum of membrane a) ENR/PVC/0\% MCC b) $\mathrm{ENR} / \mathrm{PVC} / 5 \% \mathrm{MCC}$ c) $\mathrm{ENR} / \mathrm{PVC} / 10 \% \mathrm{MCC}$ d) $\mathrm{ENR} / \mathrm{PVC} / 15 \% \mathrm{MCC}$ 

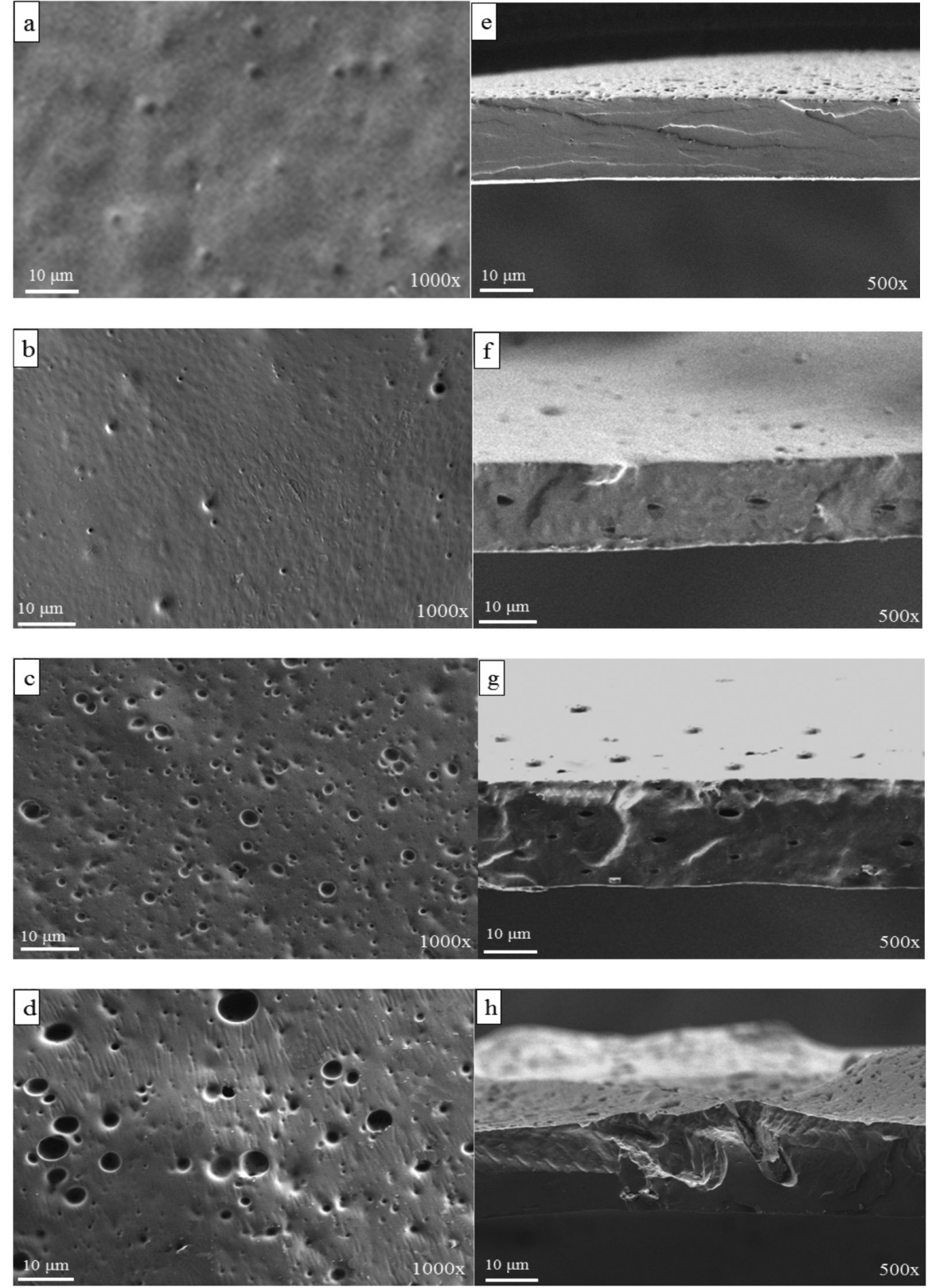

FIGURE 4. SEM micrograph of membrane surface a) ENR/PVC/0\% MCC b) ENR/PVC/5\% MCC c) ENR/ $\mathrm{PVC} / 10 \% \mathrm{MCC}$ d) ENR/PVC/15\% MCC and cross section e) ENR/PVC/0\% MCC f) ENR/PVC/5\% MCC g) $\mathrm{ENR} / \mathrm{PVC} / 10 \% \mathrm{MCC}$ h) ENR/PVC/15\% MCC

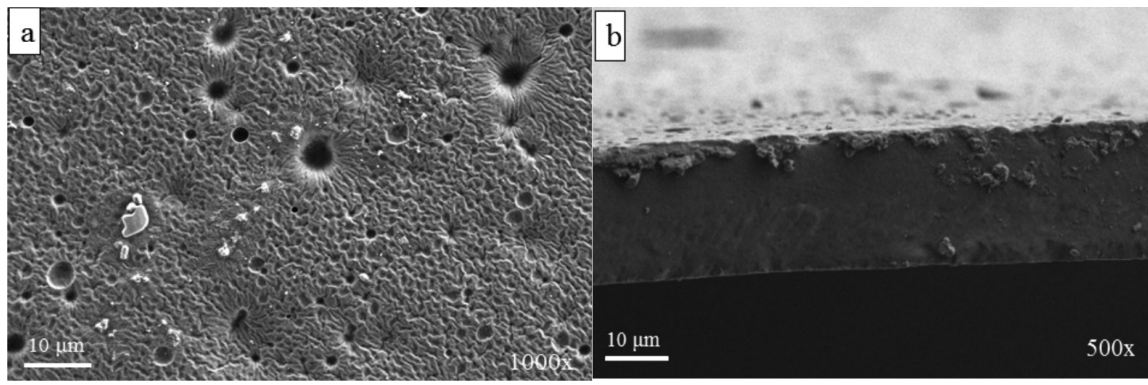

FIGURE 5. SEM micrograph of ENR/PVC/10\% MCC membrane after filtration a) surface and b) cross section 
The average of pore size and the thickness measurement by cross section of the membrane are tabulated in Table 1. The membrane pore size increased with higher MCC loadings, which was similar with the findings by Bai et al. (2015) using nanocrystalline cellulose. ENR/PVC/15\% MCC membrane had the largest pore size due to high composition of MCC loadings being added into the ENR/PVC matrix. Meanwhile, ENR/PVC/5\% MCC membrane showed the lowest thickness. The casting knife was set at $0.35 \mathrm{~mm}$ but the solvent was evaporated from the membrane surface, resulting in the ruptured structure of the membrane. Similar observations have also been reported by Mod et al. (2016).

TABLE 1. Average pore size and thickness of the ENR/PVC/MCC membranes

\begin{tabular}{lcc}
\hline Membrane & $\begin{array}{c}\text { Average pore } \\
\text { size }(\mu \mathrm{m})\end{array}$ & $\begin{array}{c}\text { Thickness of } \\
\text { membrane cross } \\
\text { section }(\mu \mathrm{m})\end{array}$ \\
\hline ENR/PVC/0\% MCC & 2.2 & 13.9 \\
ENR/PVC/5\% MCC & 3.5 & 8.9 \\
ENR/PVC/10\% MCC & 6.9 & 10.6 \\
ENR/PVC/15\% MCC & 12.3 & 12.9 \\
\hline
\end{tabular}

\section{WATER ABSORPTION AND MEMBRANE POROSITY}

Table 2 shows that the water absorption and porosity of the membranes increased when the filler loading increased. The addition of MCC into the ENR/PVC matrix caused this membrane to be more hydrophilic and absorbing more water due to the capillary effect (Alomayri et al. 2014). Zhang et al. (2016) stated that the hydrophilic character of cellulose is responsible for the water absorption in the composites and therefore higher content of filler leads to a higher amount of water absorbed. Besides, the water absorption and membrane porosity increased due to the presence of highly distributed pores in the membranes that can be proven from the SEM micrograph. Kahar and Idris (2012) reported the similar findings as the composites absorbed more water when the weight percentage of the rice husk increased. Based on the discussion earlier, the formation of pores in the membrane increased as the MCC filler increased. For ENR/PVC/15\% MCC membrane, the water absorption and porosity were the lowest compared to the other MCC added membranes. It might be due to uneven pore formation and distribution that reduced the water absorption from the surface of the membrane as the result of MCC agglomeration, similar to the findings by Zhang et al. (2017). According to Sreekala et al. (2008), as the amount of cellulose nanofibers content increases there is an increased in the number of hydroxyl groups. The number of hydroxyl group is directly proportional with the hydrogen bonding between water molecules in the composite, hence explaining the increased water uptake. At higher level of fiber loadings, the strength of the hydrogen bond formed between the matrix phase and the fiber phase increased. This might be the reason for the lower water diffusion at higher cellulose nanofiber loadings.
TABLE 2. Water absorption and membrane porosity

\begin{tabular}{ccc}
\hline \multicolumn{1}{c}{ Membrane } & $\begin{array}{c}\text { Water absorption } \\
(\%)\end{array}$ & $\begin{array}{c}\text { Porosity } \\
(\%)\end{array}$ \\
\hline ENR/PVC/0\% MCC & 12.0 & 14.1 \\
ENR/PVC/5\% MCC & 14.4 & 21.9 \\
ENR/PVC/10\% MCC & 16.1 & 26.2 \\
ENR/PVC/15\% MCC & 13.3 & 16.5 \\
\hline
\end{tabular}

\section{WATER FLUX}

Water flux is the most important test to analyze the ability of water to permeate through the membrane. Figure 6 presents the graph of water flux for ENR/PVC/MCC with different loadings. Based on the graphs, it shows that the water flux increased as the pressure increased.ENR/PVC/0\% MCC membrane does not record any water flux due to the absent of through pores formed on the membrane cross section as can be seen from Figure 4(e). The highest water flux was recorded by ENR/PVC/10\% MCC membrane. The increase in permeability of composite membrane might be attributed to the presence of microvoids (Kou et al. 2013). This statement is supported by SEM micrograph that shows uniform micropores distribution on the composite membrane. ENR/PVC/15\% MCC membrane showed the lowest flux. This is due to the agglomeration of MCC in the matrix. The uneven distribution of MCC on the membrane surface due to agglomeration had decreased the flux value as also shown by Figure 4(d). The phenomenon is in agreement with the study done by Rabiee et al. (2015) where the addition of filler that exceeds a certain value had decreased the water permeability due to the filler agglomeration. It was discovered that there were big pores on the membrane surface but in the cross section (Figure $4(\mathrm{~h})$ ), the big pores seemed to be a closed pore. The big pores on the membrane was developed as some of the agglomerated MCC leached out from the membrane during the phase inversion process (Nor \& Othaman 2015). According to Ong et al. (2015), even though many pores appeared on the surface of the membrane with higher filler compositions, the agglomerated fillers did not produce through pores that resulted in lower water flux.

The highest water flux was recorded by ENR/PVC/10\% MCC membrane. The performance of the membrane was compared with the commercial membranes such as polyethylene (PE), cellulose acetate (CA), cellulose nitrate (NC) and polytetrafluoroethylene (PTFE) membrane. The performance of water flux for each membrane at 5 bar pressure is shown in Table 3. Based on the table, the flux of ENR/PVC/10\% MCC membrane was seen to be lowered than $\mathrm{CA}, \mathrm{NC}$ and PE membranes but higher than PTFE membrane. This might be attributed to the pore size on the cross section that is smaller than the pore size on the membrane surface. Comparing to the commercial porous membranes, the prepared membranes turned out to be a dense membrane by adding the ENR while MCC as a filler, enhancer and pore former (Zahari 2017). 


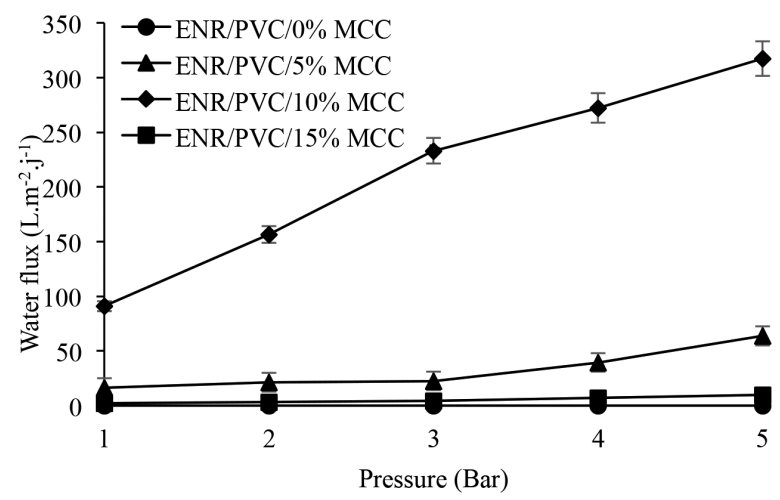

FIGURE 6. Water flux of the membrane with various filler loading

TABLE 3. Comparison of ENR/PVC/10\% MCC membrane with commercial membranes

\begin{tabular}{lc}
\hline \multicolumn{1}{c}{ Type of membrane } & Water Flux $\left(\mathrm{L} \cdot \mathrm{m}^{-2} \cdot \mathrm{j}^{-1}\right)$ \\
\hline ENR/PVC/10\% MCC & 317 \\
Polyethylene (PE)* & 12003 \\
Cellulose acetate (CA)* & 17510 \\
Cellulose nitrate (NC)* & 13202 \\
Polytetrafluoroethylene (PTFE)* & 55 \\
\hline
\end{tabular}

*Source: Zahari (2017)

\section{APPLICATION}

Based on Figure 7, the obtained result showed that POME flux increased with time. ENR/PVC/10\% MCC membrane was selected to be employed for POME treatment due to highest water flux and highly pore distribution on the membrane. The higher permeability of POME was achieved up to $3.44 \mathrm{Lm}^{-2} h^{-1}$ at 8 bar which took a longer period of time to filter due to high contents of organic matter and suspended solid in POME. Madaeni et al. (2013) stated that the material deposited on the membrane surface or within the membrane pores controls the flux. Based on the graph, it can be concluded that the membrane was still not in fouling state due to the increase of POME permeability within $6 \mathrm{~h}$ of filtration. Therefore, this membrane could be reused for second and third filtration. During filtration, the organic molecules and suspended solid were trapped on the membrane surface so that it could not pass through the pores on the membrane. Wang et al. (2006) reported

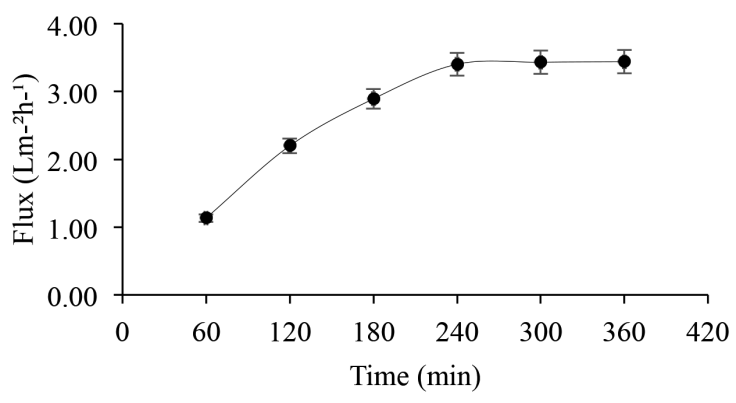

FIGURE 7. Permeability of POME through $\mathrm{ENR} / \mathrm{PVC} / 10 \% \mathrm{MCC}$ membrane

the similar observation. Subsequently, the BOD, COD and TSS of treated POME would be reduced.

The level of COD, BOD, TSS and $\mathrm{pH}$ for raw and treated POME has been analyzed from first filtration cycle until third filtration cycle. A study by Ahmad et al. (2006) reported that the removal of organic matter is required because it is a precursor to the formation of disinfection by-products when water is disinfected. After first filtration, the ENR/ PVC/10\% MCC membrane had successfully reduced the COD, BOD, and TSS level by $99.9 \%, 70.3 \%$, and $16.9 \%$, respectively, as shown in Table 4 . The parameters are within the requirement of DOE (МPOB 2014). The $\mathrm{pH}$ level of raw and treated POME was still maintained in basic condition. Ordonez et al. (2012) reported that the ability of suspended solid or organic substance to penetrate through the membrane is dependent on the size of pores formed in the membrane. However, the prepared membrane was able to compete with commercial membranes due to the good rejection of POME in terms of COD, BOD and TSS level (Table 5).

\section{CONCLUSION}

Epoxidized natural rubber/polyvinyl chloride/ microcrystalline cellulose (ENR/PVC/MCC) composite membrane with different MCC loadings has been succesfully prepared. The addition of MCC into ENR/PVC composite increased the hydroxyl group on the membranes. From SEM micrograph, it was found that the addition of MCC into the matrix caused the formation of pores on the membrane. The pores formation was increased with the increasing of MCC percentage. However, the addition

TABLE 4. Quality of raw and treated POME

\begin{tabular}{cccccccc}
\hline Parameter & $\begin{array}{c}\text { Raw POME } \\
\left(\mathrm{mgL}^{-1}\right)\end{array}$ & \multicolumn{3}{c}{ Treated POME $\left(\mathrm{mgL}^{-1}\right)$} & \multicolumn{3}{c}{ Removal efficiency $(\%)$} \\
\cline { 3 - 8 } & & $\begin{array}{c}\text { First } \\
\text { filtration }\end{array}$ & $\begin{array}{c}\text { Second } \\
\text { filtration }\end{array}$ & $\begin{array}{c}\text { Third } \\
\text { filtration }\end{array}$ & $\begin{array}{c}\text { First } \\
\text { filtration }\end{array}$ & $\begin{array}{c}\text { Second } \\
\text { filtration }\end{array}$ & $\begin{array}{c}\text { Third } \\
\text { filtration }\end{array}$ \\
\hline COD & 1793000 & 1975 & 1954 & 1941 & 99.9 & 99.9 & 99.9 \\
BOD & 320 & 95 & 70 & 50 & 70.3 & 78.1 & 84.4 \\
TSS & 1600 & 1330 & 1220 & 840 & 16.9 & 23.8 & 47.5 \\
pH & 7.72 & 8.12 & 8.17 & 8.10 & - & - & - \\
\hline
\end{tabular}


TABLE 5. Comparison of treated POME for ENR/PVC/10\% MCC membrane with commercial membranes

\begin{tabular}{cccccc}
\hline \multirow{2}{*}{ Parameter } & \multicolumn{5}{c}{ Removal efficiency $(\%)$} \\
\cline { 2 - 5 } & ENR/PVC/10\% MCC & PE* & CA $^{*}$ & NC* $^{*}$ & PTFE* $^{*}$ \\
\hline COD & 99.9 & 29 & 32 & 44 & 35 \\
BOD & 70.3 & 71 & 7 & 32 & 25 \\
TSS & 16.9 & 48.5 & 26 & 27 & 37 \\
pH & 8.12 & 8.74 & 8.64 & 9.26 & 8.28 \\
\hline
\end{tabular}

*Source: Zahari (2017)

of high MCC percentage could affect the water flux and membrane morphologies. For POME treatment, ENR/ $\mathrm{PVC} / 10 \% \mathrm{MCC}$ composite membrane was able to reduce the level of BOD, COD and TSS at each cycle of treatment within the permissible level to release to waterways. Therefore, the prepared membrane can be used to reduce the effluent with remarkable efficiency.

\section{ACKNOWLEDGEMENTS}

The authors would like to acknowledge the Polymer Research Centre UKM (PORCE), School of Chemical Sciences and Food Technology, Centre for Research and Instrumentation (CRIM), Universiti Kebangsaan Malaysia for providing the research facilities and financial support through 03-01-02SF1115 and ST-2017-008.

\section{REFERENCES}

Ahmad, A.L., Ismail, S. \& Bhatia, S. 2013. Water recycling from palm oil mill effluent (POME) using membrane technology. Desalination 157(1-3): 87-95.

Ahmad, A.L., Chong, M.F., Bhatia, S . \& Ismail, S. 2006. Drinking water reclamation from palm oil mill effluent (POME) using membrane technology. Desalination 191(1-3): 35-44.

Alomayri, T., Assaedi, H., Shaikh, F.U.A. \& Low, I.M. 2014. Effect of water absorption on the mechanical properties of cotton fabric-reinforced geopolymer composites. Journal of Asian Ceramic Societies 2(3): 223-230.

Azmi, N.S. \& Yunos, K.F.M. 2014. Wastewater treatment of palm oil mill effluent (POME) by ultrafiltration membrane separation technique coupled with adsorption treatment as pre-treatment. Agriculture and Agricultural Science Procedia 2: $257-264$.

Bai, H., Wang, X., Sun, H. \& Zhang, L. 2015. Permeability and morphology study of polysulfone composite membrane blended with nanocrystalline cellulose. Desalination and Water Treatment 53(11): 2882-2896.

Bala, J.D., Lalung, J. \& Ismail, N. 2014. Biodegradation of palm oil mill effluent (POME) by bacterial. International Journal of Scientific and Research Publications 4(3): 1-10.

Chen, W., Su, Y., Zhang, L., Shi, Q., Peng, J. \& Jiang, Z. 2010. In situ generated silica nanoparticles as pore-forming agent for enhanced permeability of cellulose acetate membranes. Journal of Membrance Science 348(1-2): 75-83.

Chong, S.S., Aziz, A.R.A. \& Harun, S.W. 2013. Fibre optic sensors for selected wastewater characteristics. Sensors 13(7): 8640-8668.

Demirel, E., Zhang, B., Papakyriakou, M., Xia, S. \& Chen, Y. 2017. $\mathrm{Fe}_{2} \mathrm{O}_{3}$ nanocomposite $\mathrm{PVC}$ membrane with enhanced properties and separation performance. Journal of Membrane Science 529: 170-184.

Ghaee, A., Shariaty-Niassar, M., Barzin, J., Matsuura, T. \& Fauzi, A. 2015. Preparation of chitosan/cellulose acetate composite nanofiltration membrane for wastewater treatment. Desalination and Water Treatment 57(31): 14453-14460.

Hassan, S., Kee, L.S. \& Al-Kayiem, H.H. 2016. Experimental study of palm oil mill effluent and oil palm frond waste mixture as an alternative biomass fuel. Journal of Engineering Science and Technology 8(6): 703-712.

JAS. 2011. Revised Standard Methods for Analysis of Rubber and Palm Oil Mill Effluent. Kuala Lumpur: Jabatan Alam Sekitar.

Jon, N., Abdullah, I. \& Othaman, R. 2013. Effect of silica on the formation of epoxidized natural rubber/polivinyl chloride membrane. Sains Malaysiana 42(4): 469-473.

Jouanneau, S., Recoules, L., Durand, M.J., Boukabache, A., Picot, V., Primault, Y. \& Lakel, A. 2014. Methods for assessing biochemical oxygen demand (BOD): A review. Water Research 49: 62-82.

Kahar, H. \& Idris, S.A. 2012. Effect of rice husks as filler in polymer matrix. Mechanical Engineering and Science 2: 181-186.

Klaysom, C., Moon, S.H., Ladewig, B.P., Lu, G.Q.M. \& Wang, L. 2011. The influence of inorganic filler particle size on composite ion-exchange membranes for desalination. Journal of Physical Chemistry C 115(31): 15124-15132.

Kou, J., Zhou, X., Chen, Y., Lu, H., Wu, F. \& Fan, J. 2013. Water permeation through single-layer graphyne membrane. The Journal of Chemical Physics 139: 1-6.

Lau, P., Ismail, A.F., Goh, P.S., Hilal, N. \& Ooi, B.S 2015. Characterization methods of thin film composite nanofiltration membranes. Separation \& Purification Reviews 44(2): 135-156

Madaeni, S.S., Khorasani, A., Asgharpour, M., Ghoreshi, S.A. \& Lotfi, M. 2013. Removal of mixtures of viruses using microfiltration membrane. Desalination and Water Treatment 51(22-24): 4313-4322.

Marbelia, L., Roil, M., Bertels, N., Laine, C. \& Vankelecom, I.F.J. 2016. Ribbed PVC-silica mixed matrix membranes for membrane bioreactors. Journal of Membrane Science 498: 315-323.

Mod, N., Anuar, F.H. \& Othaman, R. 2016. Preparation and characterization of epoxidised natural rubber (ENR)/ poly(vinylidene fluoride) (PVDF) (ENR/PVDF) composite membrane. Malaysian Journal of Analytical Sciences 20(5): 1090-1094.

MPOB. 2014. Oil Palm \& The Environment. http://www.mpob. gov.my/en/palm-info/environment/520-achievements . Accessed on 7 March 2018.

Nor, F.M. \& Othaman, R. 2015. Effects of MgO particle loading on gas permeation properties of epoxidized natural 
rubber (ENR)/polyvinyl chloride (PVC) membrane. Sains Malaysiana 44(6): 875-881.

Ong, C.S., Lau, W.J., Goh, P.S., Ng, B.C. \& Ismail, A.F. 2015. Preparation and characterization of PVDF-PVP-TiO, composite hollow fiber membranes for oily wastewater treatment using submerged membrane system. Desalination and Water Treatment 53(5): 1213-1223.

Ordonez, R., Hermosilla, D., Merayo, N., Negro, C. \& Blanco, A. 2012. Application of multi-barrier membrane filtration technologies to reclaim municipal wastewater for industrial use. Separation \& Purification Reviews 43(4): 263-310.

Rabiee, H., Vatanpour, V., Farahani, M.H.D.A. \& Zarrabi, H. 2015. Improvement in flux and antifouling properties of PVC ultrafiltration membranes by incorporation of zinc oxide (ZnO) nanoparticles. Separation \& Purification Technology 156(2): 299-310.

Rambabu, K. \& Velu, S. 2016. Improved performance of $\mathrm{CaCl}_{2}$ incorporated polyethersulfone ultrafiltration membranes. Periodica Polytechnica Chemical Engineering 60(3): 181191.

Ramesh, S., Kim, H.S. \& Kim, J.H. 2017. Cellulose-polyvinyl alcohol-nano- $\mathrm{TiO}_{2}$ nanocomposite: Thermal, optical and antimicrobial properties against pathogenic bacteria. Polymer-Plastics Technology and Engineering 57(7): 669681.

Sadr, S.M.K. \& Saroj, D.P. 2015. Membrane technologies for municipal wastewater treatment. In Advances in Membrane Technologies for Water Treatment: Materials, Processes and Applications, edited by Basile, A., Cassano, A. \& Rastogi, N.K. Surrey: Elsevier. p. 445.

Samad, N.A., Othaman, R \& Abdullah, I. 2014. Preparation and characterisation of epoxidised natural rubber/polyvinyl chloride/rice husk (ENR/PVC/RH) thin film composite by solution casting technique. International Journal of Materials Engineering Innovation 5(1): 61-69.

Shah, S.M.H., Yusof, K.W., Mustaffa, Z. \& Mustafa, A. 2014. Concentration of total suspended solids (TSS) influenced by the simulated rainfall event on highway embankment. International Journal of Engineering and Technology 6(6): 493-496.

Shamsuddin, M.R.,Abdullah, I. \& Othaman, R. 2013. Celluloses filled ENR/PVC membranes for palm oil mill effluent (POME) treatment. AIP Conference Proceedings 1571: 897-903.

Sreekala, M.S., Goda, K. \& Devi, P.V. 2008. Sorption characteristics of water, oil and diesel in cellulose nanofiber reinforced corn starch resin/ramie. Composite Interface 15(2): 281-299.
Tanjung, F.A., Hassan, A. \& Hasan, M. 2015. Use of epoxidized natural rubber as a toughening agent in plastics. Journal of Applied Polymer Science 132(29): 42270-42278.

Viet, C.X., Ismail, H., Rashid, A.A., Takeichi, T. \& Thao, V.H. 2008. Organoclay filled natural rubber nanocomposites: The effects of filler loading. Polymer Plastics Technology and Engineering 47(11): 1090-1096.

Wang, B.G., Ando, M., Yin, H., Hong, B. \& Peng, Y. 2006. Mathematical modeling of flux in ultrafiltration membrane for water treatment mathematical modeling of flux. Separation Science and Technology 41(6): 1179-1191.

Zahari, J.I. 2017. Membran getah asli terepoksida/polivinil klorida/selulosa untuk rawatan efluen minyak kelapa sawit (POME). Masters Thesis, Universiti Kebangsaan Malaysia pp. 99-108 (Unpublished).

Zhang, H., Guo, Y., Yao, J. \& He, M. 2016. Epoxidised soybean oil polymer composites reinforced with modified microcrystalline cellulose. Journal of Experimental Nanoscience 11(5): 1213-1226.

Zhang, J., Wang, Z., Liu, M., Zhao, F. \& Wu, Z. 2017. In-situ modification of PVDF membrane during phase-inversion process using carbon nanosphere sol as coagulation bath for enhancing anti-fouling ability. Journal of Membrane Science 526: $272-280$

Aina Aqila Arman Alim \& Rizafizah Othaman* School of Chemical Sciences and Food Technology

Faculty of Science and Technology

Universiti Kebangsaan Malaysia

43600 UKM Bangi, Selangor Darul Ehsan

Malaysia

Rizafizah Othaman*

Polymer Research Centre

Faculty of Science and Technology

Universiti Kebangsaan Malaysia

43600 UKM Bangi, Selangor Darul Ehsan

Malaysia

*Corresponding author; email: rizafizah@ukm.edu.my

Received: 2 October 2017

Accepted: 10 March 2018 